\title{
SCHOLASTIC GRADUATE APTITUDE TEST AS A PREDICTOR OF STUDENTS FIRST YEAR GRADUATE STUDENTS
}

A CASE STUDY OF UNIVERSITY OF CALABAR, NIGERIA

${ }^{1}$ EZE AJI EZE, ${ }^{2}$ BASSEY MOSES EKPO, ${ }^{3}$ NDEM MAJOR

${ }^{1}$ Department of Health Information Management, College of Health Technology, Calabar, Cross River State, Nigeria

${ }^{2}$ Department of Accounting, Faculty of Management Sciences, University of Calabar, Calabar, Cross River State, Nigeria

${ }^{3}$ Department of Environmental Health, College of Health Technology, Calabar, Cross River State, Nigeria

\begin{abstract}
Graduate Aptitude Test predicts the future performance of students in first-year graduate examination of University of Calabar Cross River State, Nigeria. Specifically, the purpose of the study determined the predictive validity of 2012/2013, 2013/2014 graduate aptitude tests. The correlational research design was adopted for the study. A sample of seven hundred and seventy-three (737) students were selected for the study. The selection was done through the purposive. This was because the researcher intentionally decided to use the sample for the study because of certain characteristics or elements. Here the researcher intentionally decided to use only graduate students in 2012/2013 and 2013/2014 academic sessions in the University of Calabar. A researcher-designed proforma titled "Graduate Students' Academic Records Inventory" was the main instrument used for data collection. Face validation of the instrument was carried out by the supervisors who scrutinized and affirmed the suitability of the inventory. The reliability of the instrument was not ascertained since questionnaires were not used in the study. Regression analysis was the statistical analysis technique adopted to test the hypotheses under study tested at .05 level of significance. The result of the analysis revealed that Graduate aptitude test of 2012/2013, and 2013/2014 does not significantly predict the performance of first-year graduate CGPA. Based on the findings of the study it was recommended that Graduate Aptitude Test should be used as a valid criterion in the University of Calabar since it does not significantly predict graduate students future performance in the first graduate examination.
\end{abstract}

Keywords: Academic performance, Scholastic Graduate Aptitude Test, Predictor, Graduate Students.

\section{INTRODUCTION}

Poor academic performance of graduate students remains one of the major factors responsible for the precipitous decline in the quality of education among graduate students in the university. This manifests itself in different forms; like cases of unethical and unprofessional practices, such as laziness in academic work, shoddy presentations of assignment, and high level of absenteeism and examination malpractice. It is clear that inability to study or complete academic work successfully can make an individual not only a nuisance to himself but also the society as well. Consequently, since most of the graduate students do not have a firm grasp of lessons taught, they resort to using fraudulent means for passing examination. A large number of students enter the examination hall with pieces of papers, portion of textbooks and phones with down loaded answers just to ensure they pass the examination at all costs. It goes without saying that this situation is unacceptable for graduate education.

Cherry, (2016) maintained that aptitude test is designed to assess what a person is capable of doing or to predict what a person is able to learn or do given the right education and instruction. It represents a person's level of competency to perform a certain type of task. Such aptitude tests are often used to assess academic potential or career suitability. Such tests may be used to assess either mental or physical talent in a variety of domains. Students often encounter a variety of aptitude tests throughout school as they think about what they might like to study in college or do for as a career someday. High school students often take a variety of aptitude tests designed to help them determine what they should study in college or pursue as a career. These tests can sometimes give a general idea of what might interest students as a future career. 
International Journal of Advances in Scientific Research and Engineering (ijasre), Vol 5 (5), May-2019

Aptitude Tests access students' logical reasoning and thinking ability. They consists of multiple choice questions and are held as proper exams. The tests are strictly timed. Generally, the time given depends on the number of questions in test. Mostly, 60 to 90 seconds is given for one question. (Anderson, 2016)

An aptitude test is an examination used to determine an individual's propensity to succeed in a given activity. Aptitude tests assume that individuals have inherent strengths and weaknesses, and have a natural inclination toward success or failure in specific areas based on their innate characteristics. (Harry, 2017)

For instance, aptitude test can help identify students who, independent of educational backgrounds have the intellectual capacity to succeed at university. Predictive validity could be described as a situation when the purpose is to use an instrument to estimate some important form of behaviour that is external to the measuring instrument itself, the latter being referred to as the criterion. In essence, predictive validity is concerned with the usefulness of the test score in predicting some future performance (Kpolovie, 2010). In psychometrics, predictive validity is the extent to which a score on a scale or test predicts scores on some criterion measure. For example, the validity of a cognitive test for job performance is the correlation between test scores and supervisor performance ratings. Such a cognitive test would have predictive validity if the observed correlation were statistically significant. Predictive validity shares similarities with concurrent validity in that both are generally measured as correlations between a test and some criterion measure.

Moore and Shulock (2009) noted predictive values of high grades in course work and high CGPA increase over time for success in program completion in Institute for Higher Education Leadership and Policy, Sacramento, CA. the use of aptitude tests can help identify a student's weaknesses, strength and capacity to succeed in future academic tasks in school. Makanjuola (2005) in his submission on why POST-UME is necessary claimed that at Obafemi Awolowo University (OAU), some of the students who scored high marks in UME did not even turn up for post-UME because of fear of failure. Makanjuola is however not alone in this opinion as studies on predictive validity of UME by Omodara (2004) and Oluwatayo (2003) also supported the low predictive power of UME scores on students' academic performance in the universities. Negative and inverse relationship of UME scores with some internal criteria were also noted by Adeyemo (2008). The authors are however not calling for complete scrapping of JAMB. Despite the reasons given by many for the scrapping of UME because of its many challenges, it is supposed to be a predictive test that discriminates candidate who are ready and will achieve higher in university education. However, it is crucial to investigate whether graduate aptitude test scores, CGPA at undergraduate level can predict the future academic success of first year graduate students in the university. Also, This is the gap this study intends to fill. This study thus intends to determine if performance of students in aptitude tests predict first year graduate examination success of students in the University of Calabar, Nigeria.

\section{PURPOSE OF THE STUDY}

The main purpose of the study is to assess Graduate Aptitude Test (GAT) to predict future performance of students in first year graduate examination. Specifically, the purpose of the study determined the predictive validity of 2011/2012, 2012/2013, 2013/2014 graduate aptitude tests.

\section{RESEARCH QUESTION}

What is the predictive validity $2012 / 2013,2013 / 2014$ graduate aptitude test?

\subsection{Hypothesis}

Graduate Aptitude Test of 2012/13 and 2013/2014 do not significantly predict performance of students' in first year graduate examination (CGPA).

\subsection{Methodology}

The Correlation research design was adopted in the research study; the design is appropriate or ideal in the study because it explores the key variables which predict first year graduate students' examination performance in the university. The Graduate Aptitude Test scores for , 2012/2013 and 2013/2014 were utilized in predicting students' academic success (first year graduate examination CGPA). The population of this study consisted of all graduate students in , 2012/2013 and 2013/2014 academic sessions in the University of Calabar. The population was made up of 1372 graduate students admitted in the University of Calabar. The non-probability sampling technique involving the purposive sampling was adopted for this study. Here the researchers intentionally decided to use only graduate students of 2012/2013 and 2013/2014 academic sessions in the university of Calabar. The sample consisted of 737 graduate students between 2012/2013 and 2013/2014 academic sessions. This means that all graduate students that have aptitude test scores and had completed first year graduate examinations were used for the study. The instrument used to collect data for the study was a researcher-designed proforma titled "Graduate Student's Academic Records Inventory . The GSARI proforma use in collecting aptitude test scores for 2012/2013, 2013/2014 and cumulative grade 
International Journal of Advances in Scientific Research and Engineering (ijasre), Vol 5 (5), May-2019

point average of undergraduate level, year graduate examination CGPA of students in the university. Data collected were analysed using linear regression analysis tested at 0.05 level of significance.

\section{PRESENTATION OF RESULTS}

In this section each hypothesis is re-stated, and the result of data analysis carried out to test it is presented. Each hypothesis of the study was tested at 0.05 level of significance.

Hypothesis one

Graduate aptitude test of , 2012/2013 and 2013/2014 do not significantly predict performance of students' in first year graduate examination.

The independent variable in this hypothesis is Graduate aptitude tests of 2012/2013 and 2013/2014 academic sessions while the dependent variable is first year graduate examination (CGPA). Regression analysis was used to test this hypothesis. The result is presented in Tables 1 to 3 .

TABLE 1. Summary of linear regression analysis for the contribution of Graduate aptitude test of 2012/2013 on performance of students' in first year graduate examination (CGPA $(\mathrm{N}=203)$

$\mathrm{R}=.024 ;$ Adjusted $\mathrm{R}^{2}=.004 ;$ Beta $=.024$

\begin{tabular}{lllccc}
\hline Source of Variation & Sum of Square & Df & Mean square & F-ratio & p-level \\
\hline Regression & .042 & 1 & .042 & .113 & .737 \\
Residual & 75.179 & 201 & .374 & & \\
Total & 75.222 & 202 & & & \\
\hline
\end{tabular}

$\mathrm{p}>.05$

Table 1 showed that the analysis of variance in the regression output produced an F-ratio of .113, which was not statistically significant at .05 probability level. On the basis of this result, hypothesis two was upheld. This means that, Graduate aptitude test of 2012/2013 does not significantly influence performance of students' in first year graduate examination. The positive beta weight (.024), indicated that Graduate aptitude test of 2012/2013 contributed positively to performance of students' in first year graduate examination. That is, the better the performance in Graduate aptitude test of 2012/2013, the more likely the performance of students' in first year graduate examination will be better, and vice versa. The results also show adjusted coefficient of determination $\left(\mathrm{R}^{2}\right)$ of .004 .

This implies that, $.4 \%$ of the variance in performance of students' in first year graduate examination was accounted for by Graduate aptitude test of $2012 / 2013$. Thus, $99.6 \%$ of the variance in performance of students' in first year graduate examination may be attributed to the effect of other variables extraneous to the study.

TABLE 2. Summary of linear regression analysis for the contribution of Graduate aptitude test of 2013/2014 on performance of students' in first year graduate examination( $N=128)$

$\mathrm{R}=.055 ;$ Adjusted $\mathrm{R}^{2}=.005 ;$ Beta $=.055$

\begin{tabular}{lllccc}
\hline Source of Variation & Sum of Square & Df & Mean square & F-ratio & p-level \\
\hline Regression & .160 & 1 & .160 & .378 & .540 \\
Residual & 53.309 & 126 & .423 & & \\
Total & 53.469 & 127 & & \\
\hline
\end{tabular}

$\mathrm{p}>.05$

Table 2 showed that the analysis of variance in the regression output produced an F-ratio of .378, which was not statistically significant at .05 probability level. On the basis of this result, hypothesis three was upheld. This means that, Graduate aptitude test of 2013/2014 does not significantly influence performance of students' in first year graduate examination. The positive beta weight (.055), indicate that Graduate aptitude test of 2013/2014 contributes positively to performance of students' in first year graduate examination. That is, the better the performance in Graduate aptitude test of 2013/2014, the more likely the performance of students' in first year graduate examination will be better, and vice versa. The results also show adjusted coefficient of determination $\left(\mathrm{R}^{2}\right)$ of .005 . 
International Journal of Advances in Scientific Research and Engineering (ijasre), Vol 5 (5), May-2019

This implies that, $.5 \%$ of the variance in performance of students' in first year graduate examination was accounted for by Graduate aptitude test of 2013/2014. Thus, $99.5 \%$ of the variance in performance of students' in first year graduate examination may be attributed to the effect of other variables extraneous to the study.

\section{DISCUSSION OF FINDINGS}

The result further revealed that Graduate aptitude test of 2012/2013 does not significantly predict performance of students' in first year graduate examination (CGPA). The finding of this hypothesis is in line with view of Camara and Echternacht (2000) who reported that studies that have been conducted about the predictive validity of high school performance and the achievement are not best predictors of future class room achievement. Ramist, Lewis and Mc Camley Jenkins (1994) also found that high school performance predicts better than the scholastic aptitude test (SAT). In more than 2,000 studies conducted by 685 colleges with the assistance of the college entrance examination board, Validity study services stated that total SAT score account for $18 \%$ of the variance in first year colleges CGPA. Researchers have conducted numerous studies on the predictive validity of aptitude test and CGPA at undergraduate level as criteria for admission. Some argued that lower level examinations like Aptitude Tests cannot predict first year graduate success in the university.

The result finally revealed that Graduate aptitude test of 2013/2014 does not significantly predict performance of students in first year graduate examination (CGPA).

The finding of this hypothesis is in agreement with the view of Mulu (2012) who found out that there is no significant relationship between the students university graduate aptitude test score and the first year performance in Wolaita-soddo University Ethiopia. He also indicated that students' aptitude test score is not a better predictor of future academic success. At this point, it can be said that the problem may not necessarily be with the university aptitude test examination; rather the placement/admission decision made in the results seems to be the major problem.

Omodara (2004) and Oluwatayo (2003) also supported the low predictive power of UME scores on students' academic performance in the universities. Negative and inverse relationship of UME scores with some internal criteria were also noted by Adeyemo (2008). The authors are however not calling for complete scrapping of JAMB. Despite the reasons given by many for the scrapping of UME because of its many challenges, it is supposed to be a predictive test that discriminates candidate who are ready and will achieve higher in university education.

\section{CONCLUSION}

Based on the results and findings of the study, it was concluded that; Graduate aptitude test for 2012/2013, and 2013/2014 does not significantly predict performance of students in first year graduate examination (CGPA). It was also concluded that Graduate students' Cumulative grade point averages at undergraduate level, academic discipline and gender when taken together, significantly predict performance of students in first year graduate examination (CGPA).

\section{RECOMMENDATIONS}

In the light of the above findings and conclusion, the following recommendations are proffered: The University of Calabar graduate school should utilize undergraduate CGPA as criteria for admission selection and depend less on aptitude test scores.

\section{REFERENCES}

1. Adeyemo, E. O. (2008). A meta-analysis of empirical studies on the validity of UME in Nigeria. Ph.D dissertation, Faculty of Education, Obafemi Awolowo University, Ile-ife.

2. Anderson, S., (2017) Importance of an Aptitude test in education, available online: https://targetstudy.com/articles/importance-of-an-aptitude-test-in-education.html

3. Armstrong, W. B., \& Carty, H. M. (2003). Reconsidering the SAT-1 for college admission: Analysis of alternate predictors of college success. Annual meeting of the American Educational Research Association, 1, 2-27.

4. Bacon, D., \& Bean, B. (2006). CGPA in research studies: An invaluable but neglected opportunity. Journal of Marketing Education, 28(1) 35-42.

5. Bridgeman, B., McCamley-Jenkins, L., \& Ervin, N. (2000). Predictions of freshman grade-point average from the revised and recentered SAT[R] I: Reasoning test. College Board Research Report. Full text from ERIC available online: http://www.eric.ed.gov/contentdelivery/servlet/ERICServlet?accno=ED446593

6. Camara, W. J., \& Echternacht, G. (2000). The SAT I and high school grades: Utility in predicting success in college. College Board Research Notes (RN-10). New York: College Board.

7. Cherry, K., (2016). What is an Aptitude Test?: Students Resources. Available online: https://www.verywellmind.com/what-is-an-aptitude-test-2794806 
International Journal of Advances in Scientific Research and Engineering (ijasre), Vol 5 (5), May-2019

8. Donnelly, R. (2006). Graduate entry medicine in the UK: GAMSAT-based selection \& learning outcomes. International workshop on aptitude tests for admission to medical school. 1-4 March, 2006. Tokyo, Japan.

9. Emaikwu, S. (2012). Issues in test items bias in public examinations in Nigeria and implications for testing. International Journal of Academic Research in progressive Education \& Development, 1(1), 175-187

10. Harry, M., (2016) Aptitude Test, available online: https://www.investopedia.com/terms/a/aptitudetest.asp\#ixzz5PNvXGVso

11. Kpolovie, P. J. (2010). Advanced Research Methods. New Owerri, Imo State: Springfied publisher Ltd.

12. Makanjuola, R. (2005). Why POST-UME test is necessary. The Punch Newspaper, $22^{\text {nd }}$ November, 2005 , p.34.

13. Moore, C., \& Shulock, N. (2009). Students' progress towards degree completion: Lesson from the research literature. Sacramento, CA: Institute for Higher Education Leadership \& Policy.

14. Mulu, N. (2012). Quality and quality assurance in Ethiopia Higher education: critical issues and practical implementations. University of Twente, published by CHEPS/UT.

15. Oluwatayo, J. A. (2003). Mode of entry and performance of Nigerian university undergraduate in science courses. Ph.D. dissertation, Faculty of Education, University of Ado-Ekiti.

16. Omodara, M. F. (2010). Assessment of the predictive validity of UME scores on academic performances of science University undergraduates. Multidisciplinary Journal of Research Development, 14(1), 66-71.

17. Ramist, L., Lewis, C., \& McCamley-Jenkins, L. (1994). Student group differences in predicting college grades: Sex, language, and ethnic groups (College Board Research Report. No.93-1). New York: The College Board.

18. Sireci, S., \& Talento-Miller, E. (2006). Evaluating the predictive validity of graduate management admission test scores. Journal of Educational and Psychological Measurement, 66(2) 305-317. 